\title{
ENDOTHELIAL CELL COUNT AFTER COMBINED PHACOVITRECTOMY VERSUS PHACOEMULSIFICATION FOLLOWING PARS PLANA VITRECTOMY
}

\author{
Rama Kalantri ${ }^{1}$, Tamal Roy², Krishnapada Baidya ${ }^{3}$
}

${ }^{1}$ Fellow, Department of Ophthalmology, Sankar Netralaya, Kolkata, West Bengal.

${ }^{2}$ Assistant Professor, Department of Ophthalmology, Malda Medical College and Hospital, Malda, West Bengal.

${ }^{3}$ Associate Professor, Department of Ophthalmology, Regional Institute of Ophthalmology, Kolkata, West Bengal.

\section{ABSTRACT}

\section{BACKGROUND}

To compare corneal endothelial cell count (ECC) after one-step surgery: combined phacoemulsification-IOL and pars planavitrectomy (PPV) with that after two-step surgery- PPV followed by phacoemulsification-IOL after at least 2 months of the first procedure.

Purpose- After reviewing the available literature, we did not find studies on the above stated topic. This study may prove helpful to the surgeon in considering one-step combined phacoemulsification-IOL and pars planavitrectomy for the patient.

\section{MATERIALS AND METHODS}

62 patients (65 eyes) who underwent one-step phacovitrectomy (33 eyes of 32 patients; group 1) and two-step surgery- PPV followed by phacoemulsification-IOL (32 eyes of 30 patients; group 2) were enrolled in this study. The Corneal endothelial cell count of both the groups were compared with the baseline values of the respective groups at the end of 3months and 6 months after surgery and cell count of both the groups were compared.

\section{RESULTS}

The mean endothelial cell loss in group $2(22.67 \% \pm 19.49 \%$ and $23.82 \% \pm 18.96 \%$ at 3 and 6 months respectively) was significantly higher than that in group $1(16.1 \% \pm 9.62 \%$ and $15.08 \% \pm 11.24 \%$ at 3 and 6 months respectively) $[\mathrm{p}=0.0024$ and $\mathrm{p}=0.0022$ at 3 months and 6 months respectively].

\section{CONCLUSION}

Corneal endothelial cell loss was found more in Group-2 patients; may be due to complications following first surgery and due to more tissue handling.

\section{KEYWORDS}

Endothelial Cell Count, Phacoemulsification, Pars Plana Vitrectomy.

HOW TO CITE THIS ARTICLE: Kalantri R, Roy T, Baidya K. Endothelial cell count after combined phacovitrectomy versus phacoemulsification following pars plana vitrectomy. J. Evolution Med. Dent. Sci. 2017;6(9):730-732, DOI: 10.14260/Jemds/2017/157

\section{BACKGROUND}

Endothelial cell density and morphology is a key indicator when evaluating and maintaining corneal health. In young, healthy patients, corneal endothelium appears as an array of hexagonal cells of similar size. The endothelial cell density decreases slowly as we age, and it can decline much more rapidly in certain disease states, in corneal transplants and after trauma, including surgical trauma. As endothelial cells die off, the remaining cells expand laterally and migrate, as needed, to cover the inner corneal surface; as they do so, they become less regular in size and shape. The corneal endothelium can be imaged with specular or confocal microscopes.

Financial or Other, Competing Interest: None.

Submission 19-12-2016, Peer Review 15-01-2017,

Acceptance 21-01-2017, Published 30-01-2017.

Corresponding Author:

Dr. Tamal Roy,

Premier Residency, Block No. 2

Flat No. 3A, 236 Briji West,

Near Kancha V.I.P, Garia,

Kolkata-84, West Bengal.

E-mail: tamal_oph@yahoo.com

DOI: $10.14260 /$ jemds $/ 2017 / 157$

\section{(c) $(1)$}

It has been demonstrated that the duration of ocular surgery, such as cataract and vitreoretinal surgery, is related to ocular surface damage, such as goblet cell loss and tear film instability, and also endothelial cell loss. Some vitreo-retinal surgeons prefer to do phacoemulsification with intra-ocular lens implantation (IOL) and Vitrectomy in the same sitting (One step surgery) and some prefer to do Vitrectomy followed by Phacoemulsification with IOL implantation, means two step surgery. Very little is known about the endothelial cell damage between these one step and two step procedures. So, in our present study, we have concentrated on the endothelial cell damage between these two procedures.

\section{MATERIALS AND METHODS}

62 patients (65 eyes) who underwent one-step phacovitrectomy (33 eyes of 32 patients; group 1) and twostep surgery- PPV followed by phacoemulsification-IOL (32 eyes of 30 patients; group 2) were enrolled in this study.

The age of patients was 50 to 65 years. The groups were selected on the basis of age and sex matched criteria.

Group 1 patients had prior cataract (nuclear sclerosis grade II and above) which was graded by Lens Opacities Classification System-II (LOCS-II). 
Group 2 patients were selected only when they developed visually disturbing cataract after the first surgery, posterior segment visualisation was difficult or silicone oil removal was required.

All patients gave informed written consent.

They underwent best corrected visual acuity check-up, anterior segment examination on slit-lamp, applanation tonometry, slit-lamp biomicroscopy and indirect ophthalmoscopic examination before and after surgery on each visit.

All patients had one pre-operative baseline central corneal endothelial cell count calculated with specular microscopy (Model SP2000P Topcon Corporation). It was repeated at 3 and 6 months after surgery.

All the cases were operated by the same surgeon during August 2013 to October 2014 in Regional Institute of Kolkata.

\section{RESULTS}

The mean baseline ECC of group 1 patients were $2927.82 \pm 484.41$ and that of group 2 were $2720.25 \pm 658.37$.

At 3 and 6 months, group 1 had a mean endothelial cell count of $2456.44 \pm 437.81$ and $2414.02 \pm 410.01$ respectively.

In group 2 , the value was $2103.57 \pm 530.05$ and $2072.32 \pm$ 515.62 at 3 and 6 months respectively.

The mean endothelial cell loss in group $2(22.67 \% \pm$ $19.49 \%$ and $23.82 \% \pm 18.96 \%$ at 3 and 6 months respectively) was significantly higher than that in group $1(16.1 \% \pm 9.62 \%$ and $15.08 \% \pm 11.24 \%$ at 3 and 6 months respectively) [p=0.0024 and $\mathrm{p}=0.0022$ at 3 months and 6 months respectively].

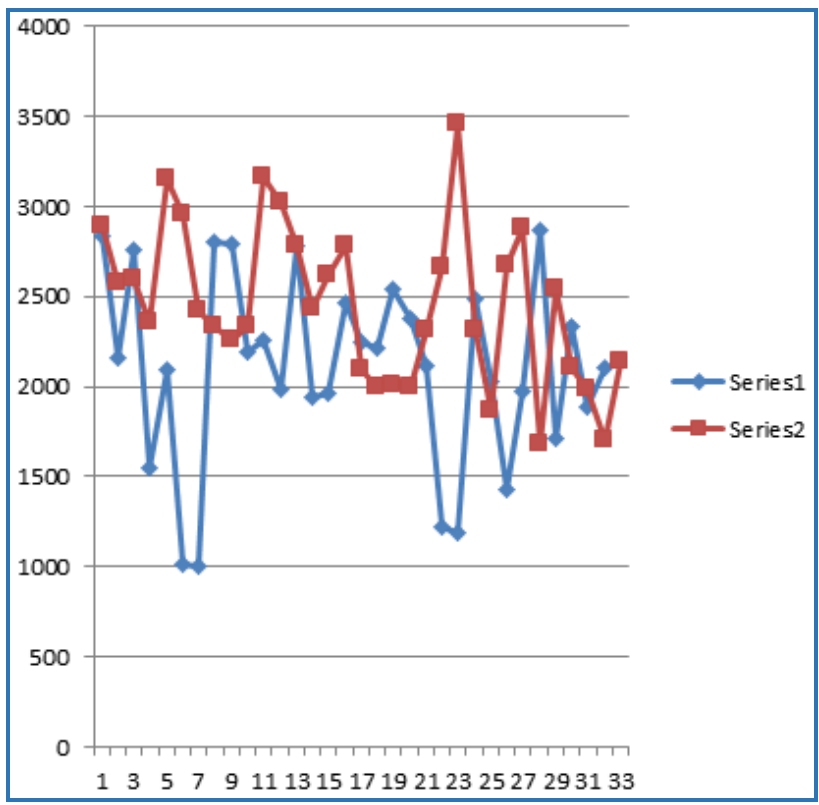

Endothelial Cell Count at 3 months (Group 2 blue)

Mean in group 1. 2456.44 \pm 437.81 , In Group 2. $2103.57 \pm$ 530.05

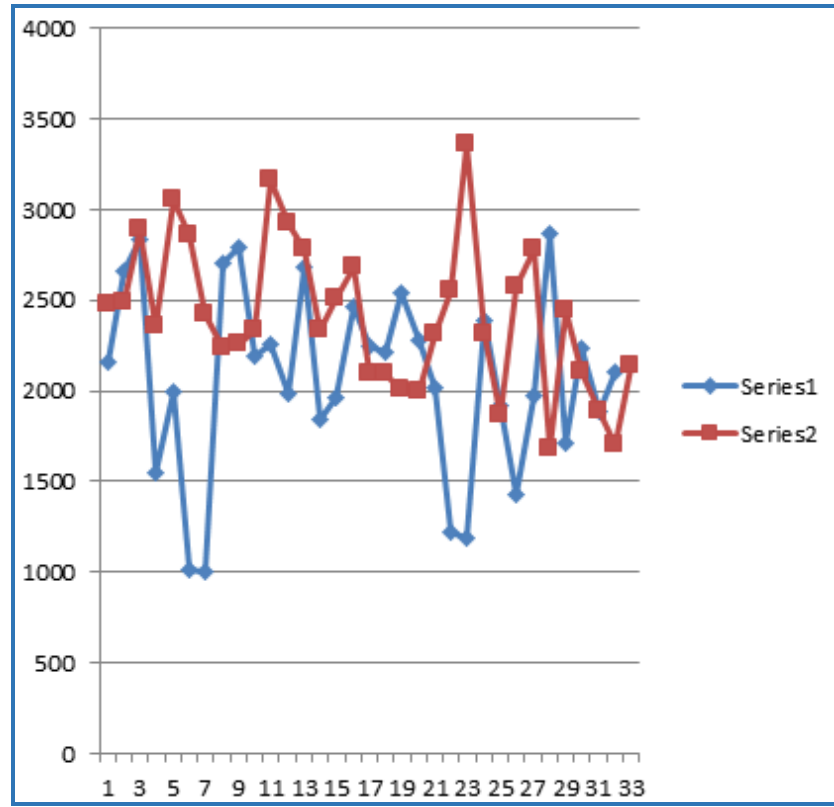

Endothelial cell count at 6 months (Group2 blue)

Mean in Group 1. and 2414.02 \pm 410.01 , in Group 2. $2072.32 \pm 515.62$.

\begin{tabular}{|c|c|c|}
\hline $\begin{array}{l}\text { Mean Cell } \\
\text { Loss } \\
\text { (3 Months) }\end{array}$ & $16.1 \% \pm 9.62 \%$ & $22.67 \% \pm 19.49 \%$ \\
\hline $\begin{array}{l}\text { Mean Cell } \\
\text { Loss } \\
\text { (6 Months) }\end{array}$ & $15.08 \% \pm 11.24 \%$ & $23.82 \% \pm 18.96 \%$ \\
\hline $\begin{array}{c}\text { Duration } \\
\text { Between } 1^{\text {st }} \\
\text { and } 2^{\text {nd }} \\
\text { Surgery }\end{array}$ & & $\begin{array}{c}\text { 2-8 months (5 cases } \\
\text { with silicone oil } \\
\text { developed early } \\
\text { cataract) }\end{array}$ \\
\hline BCVA & \begin{tabular}{|} 
Improved in 28 \\
eyes (84.8\%), \\
not improved in 5 \\
eyes (15.2\%) \\
Among the 5 eyes \\
with non- \\
improvement \\
2 was with diabetic \\
retinopathy \\
(DR), 1 was with \\
long standing \\
retinal detachment \\
(RD), 2 was with \\
macular hole (MH)
\end{tabular} & $\begin{array}{c}\text { Improved in } 24 \text { eyes } \\
\text { (75\%), not improved in } \\
8 \text { eyes (25\%) } \\
\text { Among the } 8 \text { eyes } \\
\text { with non-improvement } \\
1 \text { was with DR, } 1 \\
\text { was with long standing } \\
\text { RD, } 1 \text { was with MH, } 1 \\
\text { had macular scar, } 2 \\
\text { cases developed } \\
\text { persistent corneal } \\
\text { oedema, } 1 \text { developed } \\
\text { RD, } 1 \text { had macular } \\
\text { oedema (at } 6 \text { month) }\end{array}$ \\
\hline $\begin{array}{l}\text { Complications } \\
\text { Faced During } \\
\text { Surgery }\end{array}$ & $\begin{array}{l}\text { Phaco+IOL+PPV } \\
\text { was uneventful in } \\
\text { all cases. Single } \\
\text { piece foldable } \\
\text { PCIOL implantation } \\
\text { done in all cases. In } \\
4 \text { cases silicone oil } \\
\text { removal also done } \\
\text { at same sitting }\end{array}$ & \begin{tabular}{|} 
1 subluxated lens \\
developed RD as \\
nucleus drop took place \\
(Reattachment done \\
but recurrent RD \\
developed) \\
2 cases with \\
subluxation of lens \\
developed persistent \\
corneal oedema as the \\
$2^{\text {nd }}$ procedure became
\end{tabular} \\
\hline
\end{tabular}




\begin{tabular}{|c|c|c|}
\hline & & $\begin{array}{c}\text { difficult (1 required } \\
\text { CTR). } 1 \text { case developed } \\
\text { large posterior capsular } \\
\text { tear (Required } \\
\text { multipiece foldable } \\
\text { PCIOL and Showed } \\
\text { macular oedema at } 3 \\
\text { and 6months on Optical } \\
\text { coherence tomography) }\end{array}$ \\
\hline IOP & $\begin{array}{c}\text { Became }<20 \mathrm{mmHg} \\
\text { in all cases at } 3 \\
\text { months (No } \\
\text { remaining } \\
\text { silicone oil) }\end{array}$ & $\begin{array}{c}9 \text { case at } 3 \text { months } \\
\text { and } 4 \text { cases at } 6 \text { months } \\
\text { showed }>20 \mathrm{mmHg} \\
\text { (Baseline IOP was }<20 \\
\text { mmHg in these cases). } \\
\text { None showed } \\
\text { remaining silicone oil. }\end{array}$ \\
\hline Uveitis & $\begin{array}{l}\text { Took } 1-2 \text { weeks to } \\
\text { resolve }\end{array}$ & $\begin{array}{l}\text { Took } 10 \text { days- } 1 \text { month } \\
\text { to resolve }\end{array}$ \\
\hline
\end{tabular}

N.B: DR = Diabetic Retinopathy; RD = Retinal Detachment; $\mathrm{MH}=$ Macular hole; $\mathrm{PCIOL}=$ Posterior chamber intra-ocular lens; $\mathrm{CTR}=$ Capsular tension ring

\section{DISCUSSION}

Group 2 case faced much complications like nucleus drop, subluxated lens, posterior capsular tear-making the $2^{\text {nd }}$ surgery difficult.

BCVA was also better in Group 1.

Group 2 cases also suffered from raised IOP and uveitis for long period in comparison to Group1. Probably 2nd surgery (Tissue handling twice) is responsible for this.

Data analysis in this study reveals that.

Cell Loss at 3 and 6 months>in Group2 than Group1.

Combining phaco with vitrectomy found safe by many authors (Chong-qing Yang et al.1)
Combined Phacovitrectomy and Vitrectomy alone gives rise to less endothelial cell loss in comparison to phacoemulsification-IOL alone (Mikel Mikhail et al2).

Silicone oil leads to early cataract formation (Pang MP et al. ${ }^{3}$ )

In Our study also we found less endothelial cell loss in combined phacovitrectomy procedure and observed early cataract formation in Group2 patients with silicone oil.

\section{CONCLUSION}

Probably the higher cell loss in group 2 was because of the complications during the first surgery some of which include subluxation of lens, zonular dialysis, posterior capsular tear and nucleus drop.

$2^{\text {nd }}$ surgery itself may lead to excess tissue handling, raised IOP, uveitis; which further leads to endothelial cell damage.

So, it may be concluded that PPV should be combined with Phaco+IOL whenever moderate degree of cataract is present and it may be followed in cases where silicone oil tamponade is anticipated.

\section{REFERENCES}

[1] Yang CQ, Tong JP, Lou DH. Surgical results of pars plana vitrectomy combined with phacoemulsification. Journal of Zhejiang University Science B 2006;7(2):129-32.

[2] Mikhail M, Koushan K, Beattie A, et al. Comparison of corneal endothelial cell loss among vitrectomy, phacoemulsification, and combined phacoemulsificationvitrectomy patients. Investigative Ophthalmology \& Visual Science 2012;53(14):2749.

[3] Pang MP, Peyman GA, Kao GW. Early anterior segment complications after silicone oil injection. Canadian Journal of Ophthalmology 1986;21(7):271-5. 